\title{
PENGARUH PENAMBAHAN TEPUNG KUNYIT (Curcuma domestica Valet) DALAM PAKAN TERHADAP PARAMETER HEMATOLOGI DARAH PUYUH (Coturnix-coturnix japonica) PEDAGING
}

\author{
THE EFFECT OF TURMERIC (Curcuma domestica Valet) MEAL SUPLEMENTATION ON \\ HEMATOLOGICAL PARAMETER OF QUAIL (Coturnix-coturnix japonica) BLOOD
}

\author{
Astriana Napirah*, Supadmo, dan Zuprizal \\ Fakultas Peternakan, Universitas Gadjah Mada, Jl. Fauna No. 3, Bulaksumur, Yogyakarta, 55281
}

\section{INTISARI}

Kunyit (Curcuma domestica Valet) merupakan tanaman yang telah banyak digunakan sebagai aditif pakan golongan fitobiotik pada ayam broiler. Kunyit mengandung kurkumin, suatu zat aktif yang dapat meningkatkan daya tahan tubuh unggas. Penelitian ini bertujuan untuk mengetahui efek fitobiotik kunyit terhadap profil darah puyuh pedaging. Seratus dua puluh delapan ekor puyuh pedaging dikelompokkan dalam 4 perlakuan dengan 4 ulangan berdasarkan Rancangan Acak Lengkap. Pakan yang diberikan mengandung 24\% protein kasar dan $2.900 \mathrm{kcal} / \mathrm{kg}$ metabolizable energy. Perlakuan yang diberikan adalah R0 (pakan basal $+0 \%$ tepung kunyit), R1 (pakan basal $+0,1 \%$ tepung kunyit), R2 (pakan basal $+0,5 \%$ tepung kunyit), dan R3 (pakan basal $+1,0 \%$ tepung kunyit). Peubah yang diamati adalah profil darah meliputi jumlah eritrosit, leukosit, hemoglobin $(\mathrm{Hb})$, hematokrit, total protein plasma, neutrofil, limfosit, dan monosit. Data yang diperoleh selama 42 hari masa pemeliharaan dianalisis menggunakan analisis ragam berdasarkan Rancangan Acak Lengkap dilanjutkan dengan uji beda nyata terkecil. Pemberian tepung kunyit tidak memberikan pengaruh nyata terhadap jumlah eritrosit, hematokrit, $\mathrm{Hb}$, dan kandungan total protein plasma darah puyuh. Pemberian tepung kunyit menunjukkan pengaruh $(\mathrm{P}<0,05)$ terhadap jumlah leukosit, neutrofil, limfosit, dan monosit puyuh. Penambahan tepung kunyit aras $1,0 \%$ dalam pakan puyuh pedaging secara nyata $(\mathrm{P}<0,05)$ memperlihatkan persentase neutrofil paling rendah yang menunjukkan adanya aktivitas antibakteri senyawa kurkumin yang terdapat di dalam kunyit. Hasil penelitian menunjukkan bahwa pemberian tepung kunyit sampai aras 1,0\% dalam pakan puyuh pedaging menunjukkan adanya aktivitas imunomodulator dengan menekan persentase neutrofil dan merangsang proliferasi monosit.

(Kata kunci: Kunyit, Puyuh, Profil darah)

\begin{abstract}
Turmeric (Curcuma domestica Valet) is a plant that has a numerous used as feed additive belonging to phytobiotic group on broiler chicken. Turmeric contains curcumin, an active substance which is able to stimulate poultry immunity. This experiment was done to study the effect of turmeric as phytobiotic feed additive on quail blood profile. One hundred and twenty eight quails were grouped into 4 treatments with 4 replications based on completely randomized design. Diet used contain $24 \%$ crude protein and 2,900 kcal/kg metabolizable energy. The treatments were $R 0$ (basal feed $+0 \%$ turmeric meal), $R 1$ (basal feed $+0.1 \%$ turmeric meal), $R 2$ (basal feed $+0.5 \%$ turmeric meal) and $R 3$ (basal feed $+1.0 \%$ turmeric meal). Parameters measured were quail blood profile included erithrocyte and leucocyte count, haemoglobin (Hb), hematocrite, total plasma protein, lymphocyte, monocyte and neutrophil count. Data obtained during 42 days experiment was analyzed using analysis of variance based on completely randomized design and continued using least significant difference test. Turmeric meal did not affect the erythrocyte count, hematocrit, Hb and total plasma. Feeding turmeric gave a significant effect on leucocyte, neutrophil, lymphocyte and monocyte count. Addition 1.0\% of turmeric meal in quail feed showed the lowest neutrophil percentage $(P<0.05)$, indicated antibacterial activity of curcumin contained in turmeric. The application of turmeric meal up to $1.0 \%$ in quail feed showed immunomodulatory activity by decreased neutrophil percentage and stimulated monocyte proliferation in quail blood.
\end{abstract}

(Key words: Turmeric, Quail, Blood profil)

\footnotetext{
* Korespondensi (corresponding author):

Telp. +6285241652666

E-mail: astriana_napirah@yahoo.com
} 


\section{Pendahuluan}

Kunyit (Curcuma domestica Valet) merupakan tanaman yang dapat digunakan sebagai aditif pakan golongan fitobiotik pada ayam broiler. Kunyit diketahui memiliki efek imunomodulator sehingga dapat membantu mengoptimalkan kondisi kesehatan ayam broiler. Hasil penelitian terhadap kandungan senyawa bioaktif tanaman kunyit menunjukkan bahwa kunyit mengandung antara lain senyawa kurkumin, demetoxykurkumin, bisdemetoxykurkumin dan minyak atsiri (Li et al., 2011). Kurkumin memiliki aktivitas antioksidan (Araujo dan Leon, 2001), antibakteri (Kumar et al., 2001), antiinflamasi, antiviral, anti protozoa, antifungal dan hepatoprotektor (Pavuluri et al., 2011). Kandungan minyak atsiri tanaman kunyit juga diketahui memiliki aktivitas antibakteri sehingga membantu meningkatkan daya tahan tubuh ternak terhadap serangan bakteri patogen (Chattopadhyay et al., 2004). Kumari et al. (2007) mengemukakan bahwa penggunaan tepung kunyit dalam jangka panjang (selama 6 minggu) sebanyak $1 \mathrm{~g} / \mathrm{kg}$ pakan dapat memperbaiki konsumsi pakan dan konversi pakan tanpa menimbulkan pengaruh negatif terhadap kesehatan ayam broiler.

Namun demikian, informasi mengenai pemanfaatan tepung kunyit sebagai aditif pakan pada ternak unggas selain ayam broiler ternyata masih relatif terbatas. Misalnya saja pemanfaatan tepung kunyit sebagai aditif pakan bagi ternak puyuh pedaging masih relatif terbatas informasinya, padahal puyuh pedaging merupakan salah satu unggas pedaging yang potensial untuk dikembangkan. Oleh karena itu, pengaruh pemanfaatan tepung kunyit sebagai aditif pakan terhadap kondisi kesehatan ternak puyuh dirasa perlu untuk diteliti lebih jauh.

Kondisi kesehatan ternak dapat diamati melalui pemeriksaan darah. Gambaran keadaan darah dapat menunjukkan keadaan fisiologis maupun patologis seekor ternak. Guyton (1983) menjelaskan bahwa pemeriksaan darah merupakan salah satu metode untuk menetapkan suatu diagnosis penyakit yang dapat memberi gambaran tentang keadaan patologis dan fisiologis. Kelainankelainan dalam darah atau organ-organ pembentuk tubuh ternak dapat diketahui melalui pemeriksaan darah.

Berdasarkan kerangka pemikiran tersebut, maka dilakukan penelitian yang mengkaji pengaruh penambahan tepung kunyit (Curcuma domestica Valet) terhadap kondisi kesehatan melalui pemeriksaan profil darah puyuh (Coturnix-coturnix japonica) pedaging.

\section{Materi dan Metode}

\section{Ternak dan pakan percobaan}

Ternak percobaan yang digunakan dalam penelitian ini adalah puyuh (Coturnix-coturnix japonica) jantan umur 1 hari sebanyak 128 ekor, dibagi secara acak pada 4 kelompok perlakuan yang berbeda yaitu R0 (pakan basal $+0 \%$ tepung kunyit), $\mathrm{R} 1$ (pakan basal $+0,1 \%$ tepung kunyit), R2 (pakan basal $+0,5 \%$ tepung kunyit), dan R3 (pakan basal + $1,0 \%$ tepung kunyit). Pakan yang diberikan merupakan pakan self-mixing tanpa campuran antibiotik ataupun mikotoksin binder. Pakan percobaan mengandung 24\% protein kasar dengan energi metabolis $2.900 \mathrm{kcal} / \mathrm{kg}$ dan disusun berdasarkan standar kebutuhan nutrien puyuh menurut NRC (1994). Pemberian pakan dan air minum dilakukan secara ad libitum. Untuk mencegah penyakit Newcastle Disease (ND) dilakukan vaksinasi dengan menggunakan vaksin "Avinew" pada umur 1 hari dan "Medivac ND La Sota" pada umur 21 hari.

\section{Fitobiotik}

Fitobiotik yang digunakan dalam penelitian ini adalah kunyit dalam bentuk tepung. Tepung kunyit ditambahkan ke dalam pakan basal sesuai dengan level perlakuan yang telah ditentukan. Tepung kunyit yang digunakan memiliki kandungan kurkumin rata-rata $1,29 \pm 0,028 \mathrm{ppm}$. Pengujian kandungan kurkumin tepung kunyit dilakukan di Laboratorium Penelitian dan Pengujian Terpadu (LPPT) Universitas Gadjah Mada Yogyakarta dengan menggunakan metode kromatografi lapis tipis.

\section{Pengambilan sampel darah}

Pengambilan sampel darah dilakukan saat puyuh berumur 28,35 , dan 42 hari. Darah diambil melalui vena brachialis sebanyak $1 \mathrm{ml}$ dan ditambah EDTA $(1 \mathrm{mg} / \mathrm{ml})$ guna mendapatkan whole blood (Natt dan Herrick, 1952). Sampel darah yang diperoleh selanjutnya digunakan untuk menghitung jumlah eritrosit dan leukosit (Natt dan Herrick, 1952), serta limfosit, monosit, dan neutrofil (Sastradipraja et al., 1989). Kandungan $\mathrm{Hb}$ ditentukan dengan metode Sahli dan nilai hematokrit ditentukan dengan metode Mikrohematokrit (Sastradipraja et al., 1989). Penghitungan kandungan total protein plasma darah dilakukan dengan refragtometer.

\section{Analisis data}

Data yang diperoleh dianalisis dengan menggunakan analisis ragam dalam Rancangan Acak Lengkap (RAL) dan perbedaan antar perlakuan diuji 
dengan menggunakan Uji Beda Nyata Terkecil (Least Significant Difference Test) (Gaspersz, 1991).

\section{Hasil dan Pembahasan}

Jumlah eritrosit, nilai hematokrit, dan kandungan $\mathrm{Hb}$ dalam darah puyuh pedaging tidak dipengaruhi oleh penambahan tepung kunyit di dalam pakan. Jumlah eritrosit, nilai hematokrit, dan kandungan $\mathrm{Hb}$ darah puyuh yang diperoleh dalam penelitian ini masih berada dalam kisaran normal. Lucas (1961) cit. Piliang et al. (2009) menyatakan bahwa jumlah eritrosit, nilai hematokrit, dan kandungan $\mathrm{Hb}$ darah puyuh masing-masing 3$3,78 \times 10^{6} / \mu 1, \quad 30-40 \%$ dan $10-13 \mathrm{~g} / \mathrm{dl}$. Hal ini menunjukkan bahwa kunyit tidak mengandung zatzat toksik yang dapat menyebabkan lisisnya sel eritrosit ataupun mengganggu proses pembentukan sel darah merah. Swenson (1984) menyatakan bahwa zat-zat toksin, bakteri, perbedaan tekanan osmosis, dan parasit darah dapat menyebabkan terjadinya hemolisis pada sel-sel eritrosit. Sebaliknya, jumlah eritrosit, $\mathrm{Hb}$, dan hematokrit puyuh dipengaruhi $(\mathrm{P}<0,05)$ oleh umur puyuh. Terdapat kecenderungan bahwa semakin bertambah umur puyuh, semakin meningkat jumlah eritrosit, $\mathrm{Hb}$ dan nilai hematokritnya. Pengaruh pemberian tepung kunyit terhadap jumlah eritrosit, hematokrit, dan kandungan $\mathrm{Hb}$ darah puyuh pada umur yang berbeda tersaji pada Tabel 1 .
Jumlah eritrosit, kandungan $\mathrm{Hb}$, dan nilai hematokrit darah puyuh yang diperoleh dalam penelitian ini menunjukkan bahwa ternak puyuh yang diberi tepung kunyit dalam pakannya memiliki jumlah eritrosit dan kandungan hemoglobin yang baik, sehingga menunjang kecukupan pasokan oksigen untuk proses metabolisme tubuhnya. Jumlah eritrosit yang normal juga dapat dijadikan sebagai salah satu indikator bahwa kecukupan protein dan asam amino puyuh tetap terjaga selama proses pemberian kunyit sehingga eritrosit dapat diproduksi dalam jumlah normal. Pemberian tepung kunyit dalam pakan puyuh tidak menyebabkan puyuh mengalami defisiensi nutrien yang berkaitan dengan proses pembentukan sel darah merah seperti asam amino, zat besi, dan $\mathrm{Cu}$. Piliang et al. (2009) menyatakan hal serupa bahwa nilai hematokrit (PCV), Hb, dan butir darah merah yang normal menunjukkan puyuh tidak kekurangan protein dan asam amino yang diperlukan untuk proses metabolisme tubuhnya.

Tepung kunyit juga tidak memberikan pengaruh nyata terhadap kandungan total protein plasma darah puyuh. Grasman (2002) menyatakan bahwa penentuan konsentrasi protein plasma atau protein serum dapat menyediakan data penting mengenai kesehatan dan status fisiologis, termasuk respon imun dan inflamasi. Respon antibodi dapat meningkatkan $\gamma$-globulin, sedangkan inflamasi dapat meningkatkan protein-protein fase akut positif yaitu $\alpha$ - dan $\beta$-globulin, serta menurunkan

Tabel 1. Rataan jumlah eritrosit, kandungan hemoglobin, dan nilai hematokrit (PCV) darah puyuh yang diberi tepung kunyit pada umur 28 sampai 42 hari (the average of blood erythrocyte, haemoglobin and hematocrite (PCV) of quail fed turmeric meal as feed additive at 28 until 42 days of age)

\begin{tabular}{|c|c|c|c|}
\hline \multirow{2}{*}{ Parameter/perlakuan (parameter/treatment) } & \multicolumn{3}{|c|}{ Umur puyuh (hari) (quail ages (days)) } \\
\hline & 28 & 35 & 42 \\
\hline \multicolumn{4}{|l|}{ Eritrosit $\left(10^{6} / \mu \mathrm{l}\right)\left(\right.$ eritrocyte $\left.\left(10^{6} / \mu l\right)\right)$} \\
\hline $0 \%$ tepung kunyit ( $0 \%$ turmeric meal) & $2,53 \pm 0,79^{\mathrm{x}}$ & $3,53 \pm 0,28^{y}$ & $3,95 \pm 0,11^{\mathrm{y}}$ \\
\hline $0,1 \%$ tepung kunyit $(0.1 \%$ turmeric meal) & $2,51 \pm 0,47^{\mathrm{x}}$ & $3,31 \pm 0,22^{\mathrm{y}}$ & $3,54 \pm 0,31^{\mathrm{y}}$ \\
\hline $0,5 \%$ tepung kunyit ( $0.5 \%$ turmeric meal) & $3,36 \pm 0,40^{\mathrm{x}}$ & $3,35 \pm 0,21^{\mathrm{x}}$ & $3,39 \pm 0,50^{\mathrm{x}}$ \\
\hline $1,0 \%$ tepung kunyit ( $1.0 \%$ turmeric meal) & $2,76 \pm 0,24^{\mathrm{x}}$ & $3,28 \pm 0,49^{\mathrm{x}}$ & $3,94 \pm 0,27^{y}$ \\
\hline \multicolumn{4}{|l|}{ Hemoglobin $(\mathrm{g} / \mathrm{dl})($ haemoglobin $(g / d l))$} \\
\hline $0 \%$ tepung kunyit ( $0 \%$ turmeric meal) & $8,28 \pm 1,77^{\mathrm{x}}$ & $10,20 \pm 0,42^{\mathrm{y}}$ & $10,38 \pm 0,55^{\mathrm{y}}$ \\
\hline $0,1 \%$ tepung kunyit $(0.1 \%$ turmeric meal) & $7,73 \pm 0,99^{\mathrm{x}}$ & $9,68 \pm 0,51^{\mathrm{y}}$ & $11,30 \pm 0,99^{\mathrm{z}}$ \\
\hline $0,5 \%$ tepung kunyit ( $0.5 \%$ turmeric meal) & $9,00 \pm 0,65^{\mathrm{x}}$ & $10,70 \pm 0,63^{y}$ & $10,10 \pm 1,40^{\mathrm{xy}}$ \\
\hline $1,0 \%$ tepung kunyit ( $1.0 \%$ turmeric meal) & $8,25 \pm 0,93^{\mathrm{x}}$ & $9,73 \pm 1,35^{\mathrm{xy}}$ & $10,08 \pm 1,19^{\mathrm{y}}$ \\
\hline \multicolumn{4}{|l|}{$\operatorname{PCV}(\%)$} \\
\hline $0 \%$ tepung kunyit ( $0 \%$ turmeric meal) & $31,00 \pm 4,55^{\mathrm{x}}$ & $35,75 \pm 3,30^{y}$ & $39,25 \pm 0,96^{\mathrm{y}}$ \\
\hline $0,1 \%$ tepung kunyit $(0.1 \%$ turmeric meal) & $30,50 \pm 3,87^{x}$ & $33,75 \pm 1,50^{x y}$ & $37,25 \pm 2,22^{\mathrm{y}}$ \\
\hline $0,5 \%$ tepung kunyit $(0.5 \%$ turmeric meal) & $35,75 \pm 2,75^{\mathrm{x}}$ & $34,00 \pm 1,41^{\mathrm{x}}$ & $35,00 \pm 3,74^{\mathrm{x}}$ \\
\hline $1,0 \%$ tepung kunyit ( $1.0 \%$ turmeric meal) & $32,00 \pm 1,41^{\mathrm{x}}$ & $33,75 \pm 4,27^{\mathrm{x}}$ & $39,50 \pm 1,29^{\mathrm{y}}$ \\
\hline
\end{tabular}


prealbumin, albumin, dan transferrin. Hasil penelitian menunjukkan bahwa penambahan tepung kunyit dalam pakan puyuh tidak menyebabkan terjadinya peningkatan ataupun penurunan sintesis total protein plasma dalam jumlah berlebih. Hal ini berarti bahwa faktor-faktor yang menyebabkan peningkatan atau pengurangan sintesis total protein plasma darah dapat diminimalkan. Kandungan total protein plasma puyuh justru dipengaruhi $(\mathrm{P}<0,05)$ oleh umur puyuh. Pemberian tepung kunyit aras $0,5 \%$ menyebabkan terjadinya peningkatan total protein plasma secara signifikan pada umur 35 dan 42 hari dibandingkan dengan puyuh umur 28 hari. Pengaruh tepung kunyit terhadap kandungan total protein plasma darah puyuh tersaji pada Tabel 2 .

Pemberian tepung kunyit dalam pakan puyuh pedaging secara nyata $(\mathrm{P}<0,05)$ mempengaruhi jumlah leukosit total, persentase neutrofil, limfosit, dan monosit. Davies (1960) menyatakan bahwa pada unggas, jumlah neutrofil, limfosit, dan monosit masing-masing berkisar 30,45 , dan $15 \%$ dari total leukositnya.

Pada umur 35 hari, pemberian kunyit aras $0,5 \%$ secara nyata $(\mathrm{P}<0,05)$ menurunkan jumlah leukosit puyuh. Pada semua tingkat umur, pemberian tepung kunyit aras 1,0\% dalam pakan secara nyata $(\mathrm{P}<0,05)$ menunjukkan persentase neutrofil yang paling rendah sehingga menyebabkan peningkatan yang signifikan $(P<0,05)$ pada persentase limfosit puyuh.

Rendahnya persentase neutrofil pada penambahan $1,0 \%$ tepung kunyit dapat dijadikan sebagai salah satu indikator bahwa kunyit memiliki aktivitas imunomodulator. Kunyit memiliki aktivitas antibakteri, sehingga meskipun pakan yang diberikan tidak mengandung antibiotik dan selama pemeliharaan ternak puyuh tidak diberikan obatobat antibiotik, persentase neutrofil puyuh tidak mengalami peningkatan secara berlebih. Umumnya, pada kasus-kasus penyakit infeksi bakteri, persentase neutrofil ternak akan mengalami peningkatan secara besar-besaran. Ganong (2002) menyatakan bahwa invasi bakteri ke dalam tubuh akan mencetuskan respon peradangan. Sumsum tulang dirangsang untuk menghasilkan dan melepas sejumlah besar neutrofil. Frandson (1992) menyatakan hal serupa bahwa jumlah neutrofil di dalam darah meningkat cepat pada saat terjadi infeksi yang akut.

Aktivitas antibakteri kunyit disebabkan oleh aktivitas kurkumin dan minyak atsiri kunyit. Chattophadyay et al. (2004) menjelaskan bahwa minyak atsiri dan kurkumin memiliki aktivitas antibakteri. Kumar et al. (2001) menyatakan bahwa kurkumin sebagai antibakteri menghambat produksi $\beta$-lactamase dari mikroorganisme untuk membentuk dinding sel.

Persentase neutrofil puyuh juga dipengaruhi $(\mathrm{P}<0,05)$ oleh umur puyuh. Pada semua aras perlakuan penambahan tepung kunyit, terlihat bahwa persentase neutrofil mengalami penurunan pada umur 35 dan 42 hari dibandingkan puyuh umur 28 hari. Hal ini menyebabkan terjadinya peningkatan persentase limfosit puyuh pada umur 35 dan 42 hari dibandingkan umur 28 hari. Dellman dan Brown (1989) menyatakan bahwa fluktuasi jumlah leukosit antara lain dapat disebabkan oleh pengaruh umur. Pengaruh pemberian tepung kunyit terhadap jumlah leukosit total dan diferensial leukosit puyuh tersaji pada Tabel 3.

Hasil penelitian menunjukkan bahwa penambahan tepung kunyit memberikan pengaruh nyata $(\mathrm{P}<0,05)$ terhadap persentase monosit puyuh pedaging. Pemberian tepung kunyit aras 0,5 dan $1,0 \%$ memperlihatkan persentase monosit yang lebih tinggi dibandingkan perlakuan penambahan tepung kunyit 0 dan $0,1 \%$. Hal ini menunjukkan bahwa penambahan tepung kunyit aras 0,5 dan $1,0 \%$ dalam pakan dapat menstimulasi peningkatan jumlah monosit puyuh (tetapi dalam jumlah yang tidak berlebihan) sehingga memiliki potensi imunitas yang lebih baik dibanding perlakuan lainnya.

Tabel 2. Kandungan total protein plasma darah puyuh yang diberi tepung kunyit pada umur 28 sampai 42 hari $(\mathrm{g} / \mathrm{dl})$ (the blood plasma protein of quail fed turmeric meal as feed additive at 28 until 42 days of age $(g / d l))$

\begin{tabular}{lccc}
\hline \hline \multirow{2}{*}{ Perlakuan (treatment) } & \multicolumn{3}{c}{ Umur puyuh (hari) (quail ages (days)) } \\
\cline { 2 - 4 } & 28 & 35 & 42 \\
\hline $0 \%$ tepung kunyit $(0 \%$ turmeric meal) & $2,60 \pm 1,30^{\mathrm{x}}$ & $2,50 \pm 0,35^{\mathrm{x}}$ & $3,10 \pm 0,66^{\mathrm{x}}$ \\
$0,1 \%$ tepung kunyit $(0.1 \%$ turmeric meal) & $2,80 \pm 1,47^{\mathrm{x}}$ & $2,30 \pm 0,48^{\mathrm{x}}$ & $3,45 \pm 0,53^{\mathrm{x}}$ \\
$0,5 \%$ tepung kunyit $(0.5 \%$ turmeric meal) & $1,95 \pm 0,41^{\mathrm{x}}$ & $3,68 \pm 0,79^{\mathrm{y}}$ & $4,35 \pm 1,58^{\mathrm{y}}$ \\
$1,0 \%$ tepung kunyit $(1.0 \%$ turmeric meal) & $2,20 \pm 0,28^{\mathrm{x}}$ & $2,39 \pm 1,54^{\mathrm{x}}$ & $2,78 \pm 0,39^{\mathrm{x}}$ \\
\hline
\end{tabular}

$\overline{\mathrm{x}, \mathrm{y}, \mathrm{z}}$ Superskrip yang berbeda pada baris yang sama menunjukkan perbedaan nyata $(\mathrm{P}<0,05)$ (different superscripts at the same row indicate significant differences $(P<0.05))$. 
Tabel 3. Jumlah leukosit, neutrofil, limfosit, dan monosit puyuh yang diberi tepung kunyit pada umur 28 sampai 42 hari (the leukocyte, neutrophil, lymphocyte and monocyte count of quail fed turmeric meal as feed additive at 28 until 42 days of age)

\begin{tabular}{|c|c|c|c|}
\hline \multirow{2}{*}{ Parameter/perlakuan (parameter/treatment) } & \multicolumn{3}{|c|}{ Umur puyuh (hari) (quail ages (days)) } \\
\hline & 28 & 35 & 42 \\
\hline \multicolumn{4}{|l|}{ Leukosit $\left(10^{3} / \mu 1\right)\left(\right.$ leukocyte $\left.\left(10^{3} / \mu l\right)\right)$} \\
\hline $0 \%$ tepung kunyit ( $0 \%$ turmeric meal) & $8,64 \pm 1,85^{\mathrm{a}}$ & $9,82 \pm 3,78^{\mathrm{a}}$ & $10,56 \pm 1,77^{\mathrm{a}}$ \\
\hline $0,1 \%$ tepung kunyit $(0.1 \%$ turmeric meal) & $6,55 \pm 1,49^{a}$ & $8,07 \pm 2,38^{\mathrm{ab}}$ & $7,91 \pm 1,37^{\mathrm{a}}$ \\
\hline $0,5 \%$ tepung kunyit $(0.5 \%$ turmeric meal) & $5,84 \pm 1,26^{\mathrm{a}}$ & $6,05 \pm 2,06^{\mathrm{b}}$ & $9,12 \pm 5,78^{\mathrm{a}}$ \\
\hline $1,0 \%$ tepung kunyit ( $1.0 \%$ turmeric meal) & $7,31 \pm 1,26^{\mathrm{a}}$ & $6,91 \pm 1,02^{\mathrm{ab}}$ & $7,36 \pm 1,08^{\mathrm{a}}$ \\
\hline \multicolumn{4}{|l|}{ Neutrofil (\%) (neutrophil (\%)) } \\
\hline $0 \%$ tepung kunyit ( $0 \%$ turmeric meal) & $65,50 \pm 5,51^{\mathrm{xab}}$ & $48,75 \pm 11,24^{\mathrm{ya}}$ & $33,75 \pm 13,25^{\text {ya }}$ \\
\hline $0,1 \%$ tepung kunyit $(0.1 \%$ turmeric meal) & $68,25 \pm 10,21^{\mathrm{xa}}$ & $41,00 \pm 6,83^{\text {ya }}$ & $34,50 \pm 6,76^{\mathrm{ya}}$ \\
\hline $0,5 \%$ tepung kunyit $(0.5 \%$ turmeric meal) & $62,25 \pm 13,07^{\mathrm{xab}}$ & $43,00 \pm 11,17^{\text {ya }}$ & $46,00 \pm 6,32^{\text {ya }}$ \\
\hline $1,0 \%$ tepung kunyit ( $1.0 \%$ turmeric meal) & $51,75 \pm 18,95^{\mathrm{xb}}$ & $35,00 \pm 6,06^{\mathrm{ya}}$ & $19,75 \pm 8,62^{\mathrm{zb}}$ \\
\hline \multicolumn{4}{|l|}{ Limfosit (\%) (lymphocyte (\%)) } \\
\hline $0 \%$ tepung kunyit ( $0 \%$ turmeric meal) & $29,50 \pm 7,59^{\mathrm{xab}}$ & $47,00 \pm 9,83^{\text {ya }}$ & $62,50 \pm 14,79^{\mathrm{yab}}$ \\
\hline $0,1 \%$ tepung kunyit $(0.1 \%$ turmeric meal) & $27,00 \pm 11,51^{\mathrm{xa}}$ & $55,75 \pm 6,70^{\text {ya }}$ & $63,25 \pm 7,50^{\mathrm{yab}}$ \\
\hline $0,5 \%$ tepung kunyit $(0.5 \%$ turmeric meal) & $32,50 \pm 12,06^{\mathrm{xab}}$ & $51,50 \pm 13,02^{\mathrm{ya}}$ & $48,00 \pm 5,94^{\text {хуа }}$ \\
\hline $1,0 \%$ tepung kunyit ( $1.0 \%$ turmeric meal) & $44,00 \pm 20,01^{\mathrm{xb}}$ & $60,75 \pm 6,55^{\text {ya }}$ & $74,25 \pm 7,41^{\mathrm{yb}}$ \\
\hline \multicolumn{4}{|l|}{ Monosit (\%) (monocyte (\%)) } \\
\hline $0 \%$ tepung kunyit ( $0 \%$ turmeric meal) & $4,00 \pm 2,83^{\mathrm{a}}$ & $4,00 \pm 2,16^{\mathrm{a}}$ & $3,75 \pm 2,22^{\mathrm{ab}}$ \\
\hline $0,1 \%$ tepung kunyit $(0.1 \%$ turmeric meal) & $4,75 \pm 2,22^{\mathrm{a}}$ & $3,25 \pm 1,71^{\mathrm{a}}$ & $2,25 \pm 0,96^{\mathrm{a}}$ \\
\hline $0,5 \%$ tepung kunyit $(0.5 \%$ turmeric meal) & $5,00 \pm 3,37^{\mathrm{a}}$ & $5,50 \pm 2,08^{\mathrm{a}}$ & $6,00 \pm 1,41^{\mathrm{b}}$ \\
\hline $1,0 \%$ tepung kunyit ( $1.0 \%$ turmeric meal) & $4,25 \pm 2,22^{\mathrm{a}}$ & $4,00 \pm 0,82^{\mathrm{a}}$ & $6,00 \pm 2,16^{\mathrm{b}}$ \\
\hline
\end{tabular}

${ }_{\mathrm{x}, \mathrm{y}, \mathrm{z}}$ Superskrip yang berbeda pada baris yang sama menunjukkan perbedaan nyata $(\mathrm{P}<0,05)$ (different superscripts at the same row indicate significant differences $(P<0.05))$.

a,b Superskrip yang berbeda pada kolom yang sama menunjukkan perbedaan nyata $(\mathrm{P}<0,05)$ (different superscripts at the same column indicate significant differences $(P<0.05))$.

\section{Kesimpulan}

Pemberian tepung kunyit (kandungan kurkumin $1,29 \pm 0,028$ ppm) sampai aras $1,0 \%$ dalam pakan menunjukkan adanya aktivitas imunomodulator terhadap puyuh pedaging. Tepung kunyit tidak mengandung zat-zat toksik yang dapat mengganggu proses eritropoiesis ataupun merugikan kesehatan ternak puyuh pedaging.

\section{Daftar Pustaka}

Araújo, C. A. C. and L. L. Leon. 2001. Biological activities of Curcuma longa L. Mem. Inst. Oswaldo Cruz, Rio de Janeiro. 96: 723-728.

Chattopadhyay, I., K. Biswas, U. Bandyopadhyay and R. K. Banerjee. 2004. Turmeric and curcumin: biological actions and medicinal applications. J. Curr. Sci. 87: 44-53.

Davies, G. O. 1960. Gaiger and Davies' Veterinary Patology. $4^{\text {th }}$ ed. Baillere, Tindall and Cox. London, UK.
Dellmann, H. D. and E. M. Brown. 1989. Buku Teks Histologi Veteriner Edisi Ke-3. Penerjemah: R. Hartono. UI Press. Jakarta.

Frandson, R. D. 1992. Anatomi dan Fisiologi Ternak. Edisi Keempat. Gadjah Mada University Press. Yogyakarta.

Ganong, W. F. 2002. Fisiologi Kedokteran. Edisi Ke-20. EGC. Jakarta.

Gaspersz, V. 1991. Metode Perancangan Percobaan. Armico. Bandung.

Grasman, K. A. 2002. Assesing immunological function in toxicological studies of avian wildlife. Journal of Intergrative and Comparative Biology 42: 34-42.

Guyton, A. C. 1983. Fisiologi Kedokteran. Penerjemah: Dharma A. dan Lukito. Terjemahan dari: Medical Physiology. EGC. Jakarta. 
Kumar, S., U. Naraian, S. Tripathi and K. Misra. 2001. Synthesis of curcumin bioconjugates and study for their antibacterial activities against $\beta$-lactamase producing microorganism. Bioconj. Chem. 12: 464-469.

Kumari, P., M. K. Gupta, R. Ranjan, K. K. Singh and R. Yadava. 2007. Curcuma longa as feed additive in broiler birds and its pathophysicological effects. Indian J. Exp. Biol. 45: 272-277.

Li, M., W. Yuan, G. Deng, P. Wang, P. Yang and B. B. Aggarwal. 2011. Chemical composition and product quality control of turmeric (Curcuma longa L.). Pharmaceutical Crops. 2: 28-54.

Natt, M. P. and Herrick. 1952. A new diluent for counting the erythrocytes and leucocytes of the chicken. Poult. Sci. 31: 735-737.

NRC. 1994. Nutrient Requirement of Poultry. $9^{\text {th }}$ Revised Edition. National Research Council. National Academy Press. Washington, D.C.
Pavuluri, G., S. Kumar, Hareesha, K. Madhuri and K. V. Swathi. 2011. Curcumin: the spice for life. International Journal of Pharmaceutical Chemical and Biological Sciences 1: 48-56.

Piliang, W. G., D. A. Astuti, dan W. Hermana. 2009. Pengkayaan produk puyuh melalui pemanfaatan pakan lokal yang mengandung antioksidan dan mineral sebagai alternatif penyediaan protein hewani bergizi tinggi. Prosiding seminar hasil-hasil penelitian IPB Bogor 2009. Hal: 27-39.

Sastradipraja, S. H. S. Sikar, R. Wijayakusuma, T. Ungerer, A. Maad, H. Nasution, R. Suriawinata, dan R. Hamzah. 1989. Penuntun Praktikum Fisiologi Veteriner. Pusat Antar Universitas Ilmu Hayati IPB. Bogor.

Swenson, M. J. 1984. Dukes' Physiology of Domestic Animals. $10^{\text {th }}$ ed. Cornell University Press. Ithaca and London. 